\title{
Hydrogen Peroxide in Exhaled Breath Condensate in Asthmatic Children during Acute Exacerbation and after Treatment
}

\author{
Carlo Caffarelli $^{a}$ Elena Calcinai ${ }^{\mathrm{C}}$ Laura Rinaldi $^{\mathrm{a}}$ Carlotta Povesi Dascola ${ }^{\mathrm{a}}$ \\ Luigi Terracciano ${ }^{c}$ Massimo Corradi $^{\text {b }}$ \\ a UO Clinica Pediatrica, and b Sezione di Medicina del Lavoro, Dipartimento di Medicina Clinica e Sperimentale, \\ Università degli Studi di Parma, Parma, and ' UO Pediatria, Ospedale Macedonio Melloni, Milano, Italy
}

\section{Key Words}

Asthma exacerbation $\cdot$ Biomarkers $\cdot$ Hydrogen peroxide $\cdot$ Children $\cdot$ Inflammation and oxidative stress $\cdot$ Paediatric allergy

\section{Abstract \\ Background: In asthmatics, the concentration of hydrogen peroxide $\left(\mathrm{H}_{2} \mathrm{O}_{2}\right)$ in exhaled breath condensate (EBC) has been found to be increased and to be related to airway in- flammation. Objective: The aim of this study was to deter- mine whether in children with acute exacerbation, exhaled $\mathrm{H}_{2} \mathrm{O}_{2}$ levels could be influenced by treatment and linked to airway obstruction. Methods: Twenty-two asthmatic chil- dren (mean age 9.4 years, range 6-14) with asthma exacerba- tion and 12 healthy children (mean age 11.7 years, range 7-15) were enrolled. Concentrations of exhaled $\mathrm{H}_{2} \mathrm{O}_{2}$ before and after standard treatment for asthma attack were com- pared with those of controls and with clinical observation. Asthmatic children and controls underwent spirometry and skin prick tests to common aeroallergens. Results: Exhaled $\mathrm{H}_{2} \mathrm{O}_{2}$ concentrations were significantly higher in children with asthma both before (median $0.273 \mu \mathrm{M} ; \mathrm{p}<0.001$ ) and}

after pharmacologic treatment (median $0.303 \mu \mathrm{M} ; \mathrm{p}=0.001$ ) compared to control values (median $0.045 \mu \mathrm{M}$ ). After treatment, exhaled $\mathrm{H}_{2} \mathrm{O}_{2}$ concentrations remained significantly higher in children with and without auscultatory wheezing than in controls ( $p=0.034$ and $p<0.001$, respectively). EBC $\mathrm{H}_{2} \mathrm{O}_{2}$ levels in asthmatics before treatment did not differ from those after treatment. No correlation was found between $\mathrm{H}_{2} \mathrm{O}_{2}$ and forced expiratory volume in $1 \mathrm{~s}$ values. All asthmatics but one were atopics. Conclusions: In children with acute asthma exacerbation, exhaled $\mathrm{H}_{2} \mathrm{O}_{2}$ concentrations in $\mathrm{EBC}$ are significantly elevated. In the short-term follow-up, $\mathrm{H}_{2} \mathrm{O}_{2}$ levels remain at high levels and are not correlated with lung function or improvement in symptoms.

Copyright $\odot 2012$ S. Karger AG, Basel

\section{Introduction}

Exhaled breath condensate (EBC), which is a fluid collected by cooling of exhaled air during tidal breathing, is a completely non-invasive method, easy to perform and applicable to children [1]. EBC contains a large number of molecules originating from the airways, which are ex-

\section{KARGER}

Fax +4161306 1234

E-Mail karger@karger.ch

www.karger.com (c) 2012 S. Karger AG, Basel

$0025-7931 / 12 / 0844-0291 \$ 38.00 / 0$

Accessible online at:

www.karger.com/res
Carlo Caffarelli

UO Clinica Pediatrica, Dipartimento di Medicina Clinica e Sperimentale

Università degli Studi di Parma, Via Gramsci 14

IT-43100 Parma (Italy)

Tel. +39 052170 2207, E-Mail carlo.caffarelli@unipr.it 
pired as bioaerosol [2,3], whose concentration cannot entirely be compared directly to information derived from bronchoalveolar lavage [4]. Despite methodological problems, such as lack of reference values of biomarkers from healthy subjects, full standardization of the procedure or the sensitivity of the available assays [5], markers in EBC have been proposed as a suitable method for the assessment of airway inflammation in asthmatic patients [6-9]. Increased oxidative stress, defined as an imbalance between oxidants and antioxidants, is involved in airway inflammatory diseases including asthma [10]. Activated inflammatory cells, especially eosinophils but also macrophages and neutrophils, generate several reactive oxygen species which consequently increase gene expression of inflammatory mediators, damage epithelial cells and increase bronchial hyperreactivity [11]. Superoxide anion $\left(\mathrm{O}_{2}^{-}\right)$is rapidly metabolized by superoxide dismutase to form hydrogen peroxide $\left(\mathrm{H}_{2} \mathrm{O}_{2}\right)$ which in the airways tends to evaporate in the exhaled air, and therefore, $\mathrm{H}_{2} \mathrm{O}_{2}$ in EBC may be considered a marker of oxidative stress. However, $\mathrm{H}_{2} \mathrm{O}_{2}$ is generated from a multiplicity of sources including, but not limited to, inflammatory cells and has been associated with different lung diseases [12]. Therefore, as a diagnostic means, $\mathrm{H}_{2} \mathrm{O}_{2}$ may lack specificity. Previous studies on exhaled $\mathrm{H}_{2} \mathrm{O}_{2}$ levels were performed mainly in clinically stable asthmatics, and authors reported that $\mathrm{EBC} \mathrm{H}_{2} \mathrm{O}_{2}$ values were generally high [13-15] and related to the number of eosinophils in sputum as well as to airway hyperresponsiveness intensity [16].

The treatment of children with acute asthma is based on asthma severity as assessed by clinical signs and symptoms, measurement of pulse oximetry, pulmonary function and blood gases [17]. These parameters do not take into consideration the degree of oxidative stress or inflammation in the airways. In our study, we have investigated $\mathrm{EBC} \mathrm{H}_{2} \mathrm{O}_{2}$ levels in children with acute asthma exacerbation before and after a 7-day treatment. In addition, we determined the relationship between exhaled $\mathrm{H}_{2} \mathrm{O}_{2}$ concentrations and lung function parameters.

\section{Methods}

\section{Subjects}

We conducted a study in children aged 6-14 years with physician-diagnosed asthma, whose cases were followed at two hospital-based out-patient asthma clinics. During periodical visits that were scheduled in the morning, children who had an acute episode of asthma were consecutively enrolled in this longitudinal study between February and June 2008. Children admitted to the study had a history of physician-diagnosed asthma according to international criteria [17]. Briefly, diagnosis of asthma was based on recurrent symptoms such as breathlessness, wheezing, cough and chest tightness and was confirmed through follow-up, observing the response to a bronchodilator and to anti-inflammatory treatment [17]. Children were required to have had at least three previous episodes of wheezing treated with inhaled bronchodilators. Reversibility of airflow limitation after short-acting $\beta_{2}$-agonist administration was also measured by spirometry [17]. Children were required to have a history of asthma exacerbations triggered by an acute upper respiratory tract infection or allergens. An acute upper respiratory infection was defined by a history of acute onset of rhinitis and/or otitis and/or sore throat with or without fever accompanied by erythema and/or mucosal swelling and/or purulent secretion.

Children with a history of intermittent or mild-moderate persistent asthma were admitted to this study whether they were on a pharmacologic long-term treatment with inhaled steroids, longacting $\beta_{2}$-agonists or anti-leukotrienes or not.

We excluded all subjects who met the following criteria: severe asthma attack requiring hospitalization, bronchial provocation test in the last week, chronic upper respiratory infection, chronic cardiopulmonary disease, concurrent pneumonia, nasal polyps, obesity, gastro-oesophageal reflux and aspirin-induced asthma. Aspirin-induced asthma was excluded by a history of no temporal relationship between aspirin intake and asthma symptoms. Gastro-oesophageal reflux was excluded on the basis of clinical history and physical examination [18].

Acute exacerbation was defined by evidence of wheeze, dyspnoea, tachypnoea and/or use of accessory respiratory muscle, with/without desaturation in a child with a history of asthma, and no clinical evidence of lower respiratory tract infection (fever, focal crepitations, pleuritic pain) [19]. Children who had taken systemic steroids in the last 3 weeks were excluded from the study.

A group of healthy age-matched children without asthma and atopic diseases was enrolled as control group. Other inclusion criteria were no intake of corticosteroids in the last 3 weeks and no respiratory tract infections in the last 4 weeks. Skin prick test (SPT) results to aeroallergens in the control group were negative.

\section{Study Design}

At recruitment (visit 1), children underwent physical examination. Oxygen saturation, heart rate and respiratory rate were recorded. Details of current medication were requested. SPTs were performed. Asthmatic children were treated according to international guidelines [17] after collection of an EBC sample for $\mathrm{H}_{2} \mathrm{O}_{2}$ detection and lung function measurement. Briefly, 2-4 puffs of short-acting $\beta_{2}$-agonists were given every $20 \mathrm{~min}$ to $4 \mathrm{~h}$ in relation to the severity of the symptoms. The 4-hourly administration was continued for 1 week. In case of a poor immediate response or a moderate-severe exacerbation [17], inhaled ipratropium bromide and oral corticosteroids (prednisolone $1 \mathrm{mg} / \mathrm{kg}$ / day) were given for 7 days. Oxygen was administered if oxygen saturation was $<95 \%$. During the treatment period, the parents filled in a clinical diary of coughing and wheezing (score: $0=$ none, 1 = mild, 2 = severe), as well as of drug administration. Parents were instructed to mark wheezing when the child had difficult breathing and/or musical noise in the chest like a whistle. One point was assigned to each type of drug administered per day. After 1 week of treatment, children underwent a second visit and
Caffarelli/Calcinai/Rinaldi/ Povesi Dascola/Terracciano/Corradi 
performed collection of EBC and pulmonary function. The treatment was considered effective if a child had no symptom or sign of asthma and oxygen saturation was $>95 \%$.

A control group of healthy children underwent EBC collection, SPT and measurement of lung function. All the study procedures were conducted in the morning. Each visit was performed independently by two physicians. In the case of disagreement, a third physician was consulted. The University Ethical Committee of Parma approved the protocol and all parents gave their informed consent.

\section{Methods}

EBC was collected and processed according to the American Thoracic Society/European Respiratory Society recommendations [2], using commercial condensers. Ecoscreen (Jaeger, Hochberg, Germany) with a single-exit valve, in order to separate the expiratory flow from the inspiratory flow, was available for children recruited in Milan. Turbo-Deccs (Medivac, Parma, Italy) with a one-way valve and a reliable saliva trap, connected to a collecting vial $(50 \mathrm{ml})$ by means of a tube $[20,21]$, was available for children enrolled in Parma. Each subject used the same type of condenser for both visits. The collecting temperature in TurboDeccs was $-5^{\circ} \mathrm{C}$, and in Ecoscreen, it is reported to be from -10 to $-20^{\circ} \mathrm{C}$. To each patient a nose clip was applied to exclude possible contamination of nasal origin. The children breathed tidally through the mouth for $15 \mathrm{~min}$ or for a volume equal to $2 \mathrm{ml}$, while sitting comfortably. They kept their mouth dry during EBC collection by periodically swallowing excess saliva. The collection was stopped in case of cough or excessive saliva and was restarted when the episode has resolved. Each collection was performed 10 min after the last forced expiratory manoeuvre. For each patient, approximately $2 \mathrm{ml}$ of EBC was collected in cooling vials. The collected $\mathrm{EBC}$ samples were stored at $-80^{\circ} \mathrm{C}$ in polypropylene tubes until analysed. Samples were analysed no later than 1 month after the collection. Hydrogen peroxide was measured as previously described [22, 23], spectrofluorometrically using commercial kit Amplex Red Hydrogen Peroxide (Molecular Probes, Eugene, Oreg., USA). Salivary contamination was measured by means of the colorimetric detection of $\alpha$-amylase (Infinity Amylase Reagent, Sigma, Milan, Italy).

Lung function measurement was performed according to the European Respiratory Society/American Thoracic Society guidelines [24] using an electronic spirometer (Masterscope; Jaeger, Wuerzburg, Germany). Forced expiratory volume in $1 \mathrm{~s}\left(\mathrm{FEV}_{1}\right)$, forced vital capacity (FVC), the $\mathrm{FEV}_{1} / \mathrm{FVC}$ ratio, and forced expiratory flow $25-75 \%\left(\mathrm{FEF}_{25-75}\right)$ were expressed as percentage of predicted reference values. Patients did not receive inhaled bronchodilators until at least $4 \mathrm{~h}$ before EBC collection and spirometry.

Skin prick testing was performed with a panel of standardized common allergen extracts: birch, hazel, grasses, mugwort, alternaria, cat epithelium, dog epithelium, pellitory and house dust mite. A positive SPT was defined as a wheal with a mean diameter of at least $3 \mathrm{~mm}$ greater than the saline control after $15 \mathrm{~min}$ [25].

\section{Statistics}

The distribution of the variables was assessed by the Kolmogorov-Smirnov test; normally distributed variables are presented as the mean $\pm \mathrm{SD}$, and non-normally distributed variables as the median and interquartile range (IQR). Differences between continuous variables were calculated by the Mann-Whitney test, the
Table 1. Characteristics of the 22 asthmatic children

\begin{tabular}{lc}
\hline Characteristics & Asthmatic children \\
\hline Mean age \pm SD, years & $9.4 \pm 2.70$ \\
Males/females & $15 / 7$ \\
Positive SPT & \\
$\quad$ Grasses & $16(72)$ \\
House dust mites & $12(54)$ \\
Alternaria alternata & $8(36)$ \\
Dog epithelium & $8(36)$ \\
Cat epithelium & $8(36)$ \\
Ambrosia & $5(22)$ \\
Hazel & $3(1.3)$ \\
Birch & $3(1.3)$ \\
Aspergillus fumigatus & $3(1.3)$ \\
Pellitory & $2(0.9)$ \\
Plantago lanceolata & $2(0.9)$ \\
At least one positive SPT & $21(95)$ \\
Monosensitized patients & $9(41)$ \\
Polysensitized patients & $13(59)$ \\
Long-term medications & \\
Salmeterol+fluticasone dipropionate & 7 \\
Fluticasone dipropionate & 2 \\
Montelukast & 1 \\
\hline
\end{tabular}

Figures in parentheses are percentages.

Wilcoxon signed rank test, the two-tailed Student t test or ANOVA when appropriate. The $\chi^{2}$ test or Fischer's exact test were used to compare ordinary variables. Correlations were expressed as Spearman's correlation coefficient. A p value $<0.05$ was considered statistically significant. A study group of at least 20 subjects and a control group of at least 10 subjects were determined to detect 1.25 SD difference at the $5 \%$ significance level with power $90 \%$.

\section{Results}

Twenty-two asthmatic children with acute asthma exacerbation were consecutively enrolled. Demographic and clinical characteristics are shown in table 1 . On the basis of medical history, physical examination and concordant SPT results, exacerbation was presumed to be due to seasonal allergen exposure in 16 cases and to upper respiratory tract infection in 6 cases. At visit 1, all children had wheezing documented by auscultatory wheeze, cough, shortness of breath and/or chest tightness and/or use of accessory respiratory muscle. At the second visit, 13 (61\%) of the 22 patients were asymptomatic with a normal chest auscultation. In the remaining 9 children, auscultatory wheeze was still present, without using accessory breathing muscles or dyspnoea. During the 7-day 
Table 2. Exhaled $\mathrm{H}_{2} \mathrm{O}_{2}$ concentrations $(\mu \mathrm{M})$ in controls and asthmatic children

\begin{tabular}{llll}
\hline & $\begin{array}{l}\text { Asthmatic } \\
\text { children }(\mathrm{n}=22)\end{array}$ & $\begin{array}{l}\text { Control subjects } \\
(\mathrm{n}=12)\end{array}$ & $\begin{array}{l}\mathrm{p} \\
\text { value }\end{array}$ \\
\hline Before treatment & $0.273,0.142-0.669$ & $0.045,0.017-0.082$ & 0.001 \\
After treatment & $0.303,0.122-0.723$ & & 0.001 \\
\hline
\end{tabular}

Data are presented as medians and IQRs.

Table 3. $\mathrm{H}_{2} \mathrm{O}_{2}$ values $(\mu \mathrm{M})$ in children who were on long-term treatment with inhaled glucocorticosteroids and in controls

\begin{tabular}{|c|c|c|}
\hline & Before treatment & After treatment \\
\hline $\begin{array}{l}\text { Control subjects }(\mathrm{n}=12) \\
\text { Inhaled glucocorticosteroids }\end{array}$ & \multicolumn{2}{|l|}{$0.045,0.017-0.082^{\mathrm{a}, \mathrm{b}, \mathrm{c}, \mathrm{f}}$} \\
\hline Yes $(n=9)$ & $0.25,0.16-0.49^{\mathrm{a}, \mathrm{d}}$ & $0.24,0.14-0.56^{e, f}$ \\
\hline No $(n=13)$ & $0.3,0.14-0.81^{b, d}$ & $0.38,0.12-0.72^{\mathrm{e}, \mathrm{c}}$ \\
\hline $\begin{array}{l}\text { Data are presented as me } \\
d, e p>0.05 ;{ }^{a, f} p=0.002 ;\end{array}$ & $\begin{array}{l}\text { ans and IQRs. } \\
=0.009 ;{ }^{c} p=0.001\end{array}$ & \\
\hline
\end{tabular}

treatment, all patients received salbutamol, 12 ipratropium bromide and 5 oral steroids. In asthmatics, the mean symptom-drug score at day 1 was higher than that at day 7 (3.59 \pm 1.3 vs. $2.59 \pm 1.18 ; \mathrm{p}=0.005)$; this significant difference was also observed for symptoms alone (1.82 \pm 1.01 vs. $1.05 \pm 0.95 ; p=0.006)$. At visit 2 , the symptomdrug score was higher in children with wheezing than in those free of symptoms $(\mathrm{p}=0.032)$. The maximum symptom score was 4 and the maximum symptom-drug score was 7. At the first visit, oxygen saturation was $96.9 \pm$ $0.014 \%$ (range 94-98) and at the second visit $97.6 \pm$ $0.007 \%$ (range 96-99; $p=0.726$ ). The control group consisted of 12 healthy children ( 7 males, 5 females, with a mean age of $11.7 \pm 2.75$ years, range $7-15)$.

\section{$\mathrm{H}_{2} \mathrm{O}_{2}$ Concentrations}

All patients and controls performed a correct manoeuvre for the collection of $\mathrm{EBC}$, producing a sufficient quantity for the analysis of $\mathrm{H}_{2} \mathrm{O}_{2}$. Salivary contamination was not detected in the EBC samples. At baseline and at visit 2 , in children with asthma $\mathrm{EBC}, \mathrm{H}_{2} \mathrm{O}_{2}$ values were significantly higher than those detected in healthy control children (table 2). In asthmatics, there was no significant difference in $\mathrm{EBC} \mathrm{H}_{2} \mathrm{O}_{2}$ concentrations between visit 1 and visit $2(\mathrm{p}=0.682)$. There was no statistically significant difference in $\mathrm{EBC} \mathrm{H}_{2} \mathrm{O}_{2}$ values between the two condensers used. At baseline, values of $\mathrm{EBC} \mathrm{H}_{2} \mathrm{O}_{2}$ obtained with Turbo-Deccs ( $\mathrm{n}=12,0.195 \mu \mathrm{M}$, IQR 0.144-0.379) were similar to those with Ecoscreen $(n=10,0.625 \mu \mathrm{M}$, IQR 0.158-0.912; $\mathrm{p}=0.15$ ) and higher than those of controls ( $\mathrm{p}=0.007$ and 0.001 , respectively). At visit $2, \mathrm{H}_{2} \mathrm{O}_{2}$ concentrations were $0.580 \mu \mathrm{M}$ (IQR $0.244-1.722)$ in children who used Ecoscreen and $0.180 \mu \mathrm{M}$ (IQR 0.117-0.412) in the 12 children who used Turbo-Deccs $(\mathrm{p}=0.212)$. At visit 2, $\mathrm{EBC} \mathrm{H}_{2} \mathrm{O}_{2}$ concentrations in asthmatics obtained with Turbo-Deccs or Ecoscreen were significantly higher than in healthy control children ( $\mathrm{p}=0.006$ and 0.01 , respectively).

Table 3 shows the comparison of exhaled $\mathrm{H}_{2} \mathrm{O}_{2}$ concentrations between children receiving inhaled corticosteroids as long-term treatment and those who did not. At visit 2, exhaled $\mathrm{H}_{2} \mathrm{O}_{2}$ concentrations were significantly higher in children with auscultatory wheezing $(0.18$ $\mu \mathrm{M}$, IQR $0.11-0.31$ ) and in those free of auscultatory wheezing $(0.71 \mu \mathrm{M}$, IQR $0.13-0.88)$ compared with controls $(\mathrm{p}=0.034$ and $\mathrm{p}<0.001$, respectively). However, there was no difference in $\mathrm{H}_{2} \mathrm{O}_{2}$ levels between asthmatics with auscultatory wheezing and those without $(\mathrm{p}=$ 0.061). Furthermore, in asthmatics with or without auscultatory wheezing, $\mathrm{H}_{2} \mathrm{O}_{2}$ levels were not statistically different from those detected at the first visit. At the second visit, there was no significant difference in $\mathrm{H}_{2} \mathrm{O}_{2}$ concentrations between asthmatics who received systemic steroids for exacerbation and those who did not $(\mathrm{p}=0.224)$. There was no significant correlation between $\mathrm{EBC} \mathrm{H}_{2} \mathrm{O}_{2}$ concentrations and $\mathrm{O}_{2}$ saturation (at baseline, $\mathrm{r}=0.344$, $\mathrm{p}=0.117$; at visit $2, \mathrm{r}=-0.96, \mathrm{p}=0.671)$ or symptom-drug score (at visit $2, \mathrm{r}=-0.126, \mathrm{p}=0.577$ ).

\section{Pulmonary Function}

At visit 1 , in asthmatic children, pulmonary function values were significantly lower than those of healthy control children (table 4). At visit 2, asthmatic children had $\mathrm{FEV}_{1} \%$ predicted values similar to those of controls (table 4). No significant differences were found in lung function values between baseline and visit 2 (table 4 ). Both at visit 1 and visit 2 , there was no correlation between $\mathrm{FEV}_{1}$ $\%$ predicted values, $\mathrm{FEF}_{25-75} \%$ predicted values, $\mathrm{FVC} \%$ predicted values and $\mathrm{H}_{2} \mathrm{O}_{2}$ levels, $\mathrm{O}_{2}$ saturation or symptom-drug score. At the second visit, both in children with auscultatory wheezing and in those free of symptoms, no correlation was found between $\mathrm{H}_{2} \mathrm{O}_{2}$ levels and $\mathrm{FEV}_{1} \%$ predicted values, $\mathrm{FVC} \%$ predicted values, $\mathrm{FEF}_{25-75} \%$ predicted values. 
Table 4. Lung function in controls and asthmatic children

\begin{tabular}{|c|c|c|c|}
\hline & $\begin{array}{l}\text { Control } \\
\text { subjects } \\
(n=12)\end{array}$ & $\begin{array}{l}\text { Asthmatic } \\
\text { children } \\
(\mathrm{n}=22)\end{array}$ & $\mathrm{p}$ value \\
\hline \multicolumn{4}{|l|}{$\mathrm{FEV}_{1}, \%$ predicted } \\
\hline Before treatment & $112.5 \pm 15.75$ & $94.9 \pm 11.94^{\mathrm{a}}$ & 0.004 \\
\hline After treatment & & $101.4 \pm 13.92^{\mathrm{a}}$ & 0.135 \\
\hline \multicolumn{4}{|l|}{$\mathrm{FEF}_{25-75}, \%$ predicted } \\
\hline Before treatment & $106.17 \pm 19.75$ & $76.5 \pm 18.25^{b}$ & $<0.001$ \\
\hline After treatment & & $81.91 \pm 19.33^{\mathrm{b}}$ & 0.001 \\
\hline \multicolumn{4}{|l|}{ FVC, \% predicted } \\
\hline Before treatment & $104.66 \pm 14.33$ & $84.36 \pm 14.42^{\mathrm{c}}$ & 0.001 \\
\hline After treatment & & $89.62 \pm 15.77^{\mathrm{c}}$ & 0.017 \\
\hline
\end{tabular}

Data are presented as the mean $\pm \mathrm{SD}$.

${ }^{\mathrm{a}} \mathrm{p}=0.105 ;{ }^{\mathrm{b}} \mathrm{p}=0.481 ;{ }^{\mathrm{c}} \mathrm{p}=0.33$.

\section{Discussion}

The results of the present study show that mean levels of $\mathrm{H}_{2} \mathrm{O}_{2}$ in EBC are significantly higher in children with asthma exacerbation than in normal control subjects and remained elevated after a 7-day treatment [17].

In agreement with our results, Dohlman et al. [15] found that 3 out of 4 children with acute exacerbation had higher $\mathrm{EBC} \mathrm{H}_{2} \mathrm{O}_{2}$ concentrations than controls. Our results extend previous findings by examining a greater number of patients. Furthermore, to our knowledge, this is the first report providing data on exhaled $\mathrm{H}_{2} \mathrm{O}_{2}$ concentration in the short-term follow-up of exacerbation. Dohlman et al. [15] reported no differences in exhaled $\mathrm{H}_{2} \mathrm{O}_{2}$ levels between asthmatic children with acute asthma and those with upper respiratory infections, not accompanied by asthmatic symptoms. Our study design does not permit to exclude that a coexistent upper respiratory infection may have enhanced $\mathrm{H}_{2} \mathrm{O}_{2}$ levels. Future research may clarify this issue. Our findings cannot be directly compared with earlier investigations of EBC $\mathrm{H}_{2} \mathrm{O}_{2}$ concentrations focused on asthmatics who were free of asthmatic symptoms. Consistent with previous observations, data showed significantly increased exhaled $\mathrm{H}_{2} \mathrm{O}_{2}$ levels in asthmatic children with [15] and without upper respiratory tract infections [14] as well as in adults $[10,16,17]$ with asthma, even if there was an overlapping with the levels of controls $[10,14-16,26]$. At variance, Robroeks et al. [27] found no difference in EBC $\mathrm{H}_{2} \mathrm{O}_{2}$ levels between childhood asthmatics and controls. Different methods used to detect $\mathrm{EBC} \mathrm{H}_{2} \mathrm{O}_{2}$ concentrations may explain these different findings.

Hydrogen Peroxide in Acute Asthmatic Exacerbation
EBC collection is not yet fully standardized and several issues need to be considered in interpreting concentrations of EBC constituents [2, 28]. For example, we followed the suggestion of collecting EBC 10 min or more after forced expiratory manoeuvers. However, there is no consensus in this recommendation [2]. At present, there is no evidence showing that changes in airway caliber cause any difference in mediator release or dilution of EBC $[29,30]$, but this question has not been studied systematically. Another issue is the flow dependence of exhaled $\mathrm{H}_{2} \mathrm{O}_{2}$ levels. We are aware that, in one study only, exhalation flow influences the level of exhaled $\mathrm{H}_{2} \mathrm{O}_{2}$; at higher flows, exhaled $\mathrm{H}_{2} \mathrm{O}_{2}$ concentration is lower, but with the low flows during tidal breathing, the effect is minor [31]. However, symptomatic children have higher breathing rates and may have higher minute ventilation, which could theoretically influence the results. We did not take into consideration the control of minute ventilation as it is not requested by the recommendation [2]. We believe that if a bias could have been present because of that, it could probably have randomly affected the sample. We think that this factor deserves attention, and therefore, we would like to standardize exhalation flow ventilation in the next studies, as shown by Franklin et al. [32].

Another concern is the method employed to measure EBC $\mathrm{H}_{2} \mathrm{O}_{2}$. We used the fluorometric method [33, 34], even if the lack of established reference values has not permitted to ascertain sensitivity and specificity and has hampered the validation of measurements [35]. However, data reproducibility has been shown in a previous study by Goldoni et al. [20].

Only speculative hypothesis may be offered to explain the reason for which treatment of asthma exacerbation does not affect exhaled $\mathrm{H}_{2} \mathrm{O}_{2}$ levels. In asthmatic adults, EBC $\mathrm{H}_{2} \mathrm{O}_{2}$ is related to inflammatory cells, especially the number of eosinophils in the sputum [16]. Furthermore, it is associated with neutrophils in mild but not in moderate asthma [10]. A meta-analysis of $\mathrm{EBC}_{2} \mathrm{O}_{2}$ levels in stable asthmatic patients [13] free of symptoms included 8 heterogeneous cross-sectional trials. It provided indicative evidence that patients treated with inhaled corticosteroids had exhaled $\mathrm{H}_{2} \mathrm{O}_{2}$ concentrations which were significantly lower than those in steroid-untreated patients. Furthermore, both steroid-treated and -untreated asthmatics had higher levels of $\mathrm{EBC} \mathrm{H}_{2} \mathrm{O}_{2}$ than healthy subjects [13]. Along this line, Antczak et al. [36] showed that in asthmatic children, inhaled beclomethasone significantly reduced expired $\mathrm{H}_{2} \mathrm{O}_{2}$ levels in comparison with placebo. These findings may be explained by the an- 
ti-inflammatory properties of corticosteroids which inhibit an oxidative burst of leucocytes and eosinophil recruitment to the airways. However, Horvath et al. [16] showed that asthmatic adults whose symptoms were not controlled by inhaled steroids had increased levels of EBC $\mathrm{H}_{2} \mathrm{O}_{2}$ that were not significantly different from those in stable steroid-naive asthmatics. Accordingly, we found that there was no relationship between systemic corticosteroid administration and $\mathrm{EBC} \mathrm{H}_{2} \mathrm{O}_{2}$ levels during acute asthma exacerbations. These findings support the suggestion that corticosteroid succeeds in suppressing only a part of the airway inflammation [37]. Therefore, we may hypothesize that in acute exacerbation oxidative stress may continue after health restoration possibly because of persistent inflammation in the airways despite steroid treatment. However, the small number of children treated with systemic corticosteroids and the design of the study do not consent to reach firm conclusions. On the other hand, it is possible that lack of variation in EBC $\mathrm{H}_{2} \mathrm{O}_{2}$ levels may depend on the short time between EBC collections.

The issue arises whether there is a correlation between $\mathrm{FEV}_{1}$ values and exhaled $\mathrm{H}_{2} \mathrm{O}_{2}$ levels in asthmatic children. We have found that bronchodilator treatment was effective in producing relief of airway obstruction but not in changing exhaled $\mathrm{H}_{2} \mathrm{O}_{2}$ levels. Therefore, we believe that $\mathrm{H}_{2} \mathrm{O}_{2}$ levels do not reflect changes in airway caliber despite the fact that $\mathrm{H}_{2} \mathrm{O}_{2}$ induces contraction of respiratory smooth muscles [38]. Our findings are in agreement with prior reports showing no correlation between $\mathrm{FEV}_{1}$ and $\mathrm{H}_{2} \mathrm{O}_{2}$ both in healthy [39] and asthmatic children [15] as well as in adults [16]. On the contrary, Loukides et al. [10] found a significant inverse correlation between $\mathrm{FEV}_{1}$ values and $\mathrm{H}_{2} \mathrm{O}_{2}$ levels in steroid-naive adults with moderate asthma but not in those treated with inhaled steroids. On the other hand, Antczak et al. [36] found an inverse correlation between $\mathrm{FEV}_{1}$ and $\mathrm{H}_{2} \mathrm{O}_{2}$ in children treated with inhaled beclomethasone. Variations in study design may explain our different findings. Also, the severity of asthma may play a role. In our study, we included children with acute exacerbation who did not require admission. In these children, $\mathrm{FEV}_{1}$ values are poorly correlated with the degree of wheezing, clinical score and oxygen saturation [40]. Our findings of quite high lung function values may be explained by the fact that patients were probably visited at the onset of exacerbation and symptoms usually precede the lung function decline [41].

A possible limitation of this study was that $\mathrm{EBC}$ was collected with two different devices. Two different condensers were available: Turbodeccs and Ecoscreen were used in children enrolled in Parma and in Milan, respectively. Previous studies have shown that data of Ecoscreen [42] and Turbo-Deccs [20] are both reproducible, but direct comparison between the two condensers by measuring $\mathrm{H}_{2} \mathrm{O}_{2}$ in EBC collected by the two systems in the same subject has not been done in the present study. However, the risk of bias was considered acceptable for many reasons. First, there is no clear evidence that $\mathrm{H}_{2} \mathrm{O}_{2}$ levels may be influenced by condensing devices, probably due to its partial volatility. In fact, in a previous study, Rosias et al. [42] have found that median $\mathrm{H}_{2} \mathrm{O}_{2}$ concentrations and reproducibility did not significantly differ between four different condensers. Regarding other substances, comparison of $\mathrm{pH}$ values of fluid collected from two devices (Ecoscreen and RTube) has yielded conflicting results, and therefore, neither device is preferred over the other [43]. Second, it has been shown that the cooling temperature influences levels of EBC constituents. It has been found that there was a statistically significant difference in $\mathrm{H}_{2} \mathrm{O}_{2}$ levels comparing the cooling temperature +5 and $-5^{\circ} \mathrm{C}$ but not comparing -5 and $-10^{\circ} \mathrm{C}$. [20]. In the Turbo-Deccs, the cooling temperature is dysplayed and it was set at $-5^{\circ} \mathrm{C}$. The cooling temperature of Ecoscreen is not dysplayed, but it has been reported to be from -10 to $-20^{\circ} \mathrm{C}$. Therefore, we believe that a bias was not introduced by cooling temperature. Along this line, in our study, no statistically significant difference was observed comparing exhaled $\mathrm{H}_{2} \mathrm{O}_{2}$ levels from the two condensers used. However, we cannot exclude that a significant difference may be reached with a larger group of patients. Third, in consideration of the lack of recommendations on the use of different condensers, we think that real-life situations are necessary to confirm or dismiss these unsolved points. Finally, the behavior of $\mathrm{H}_{2} \mathrm{O}_{2}$ in EBC cannot be explained on the basis of its chemical and physical properties, and the most probable explanation may be that some was produced by a radical reaction in the gas phase or during the condensation process in water, irrespectively of the devices used [44].

Another limitation of our study is the lack of randomization and of a placebo group. However, it was neither ethical nor feasible to have a placebo group in this study. This weakness is partly balanced by the fact that physicians who visited children or performed spirometry were unaware of $\mathrm{H}_{2} \mathrm{O}_{2}$ results. An additional limitation is the heterogeneity of our population, especially with regard to the fact that both children who received inhalant steroid as maintenance treatment and steroid-naive patients were included in the study. Nonetheless, our data showed that $\mathrm{H}_{2} \mathrm{O}_{2}$ concentrations in $\mathrm{EBC}$ were not influenced by
Caffarelli/Calcinai/Rinaldi/ Povesi Dascola/Terracciano/Corradi 
pre-exacerbation treatment. Therefore, we think that a bias was not introduced. However, in this study, differences among asthmatic subpopulations cannot be properly assessed because subgroup comparisons not only suffer from the limitation of any observational study but also from those due to small sample size and lack of randomization. Therefore, our results on subpopulations should be considered suggestive and may only provide directions for future research.

A potential weak point is $\mathrm{H}_{2} \mathrm{O}_{2}$ volatility. It is clear that $\mathrm{H}_{2} \mathrm{O}_{2}$ has a relatively high Henry's constant in comparison with the other substances, and so its volatility should be low (although not negligible) at temperatures of 25$37^{\circ} \mathrm{C}$. In a previous study, the volatility of $\mathrm{H}_{2} \mathrm{O}_{2}$ ex vivo was less than that of water on the basis of the differences in $\mathrm{EBC} \mathrm{H}_{2} \mathrm{O}_{2}$ content observed with variations in condensation temperature [20]. Moreover, in vitro experiments demonstrate that $\mathrm{H}_{2} \mathrm{O}_{2}$ is only slightly volatile in a standard solution at $37^{\circ} \mathrm{C}$ under a constant flow of air saturated with water vapor (only $1.3 \%$ evaporated after 3 h) [44]. Therefore, with the systems used, we cannot guarantee a complete recovery of all $\mathrm{H}_{2} \mathrm{O}_{2}$ which is exhaled and which is produced during the exhalation. However, they represent a good compromise between efficiency in collecting EBC and the stability of the biomarkers within it, because of the more efficient condensation of water obtained by using very low temperatures.

In conclusion, our study has shown that $\mathrm{H}_{2} \mathrm{O}_{2}$ levels in EBC are significantly elevated in children with acute asthma exacerbation. In the short-term follow-up, exhaled $\mathrm{H}_{2} \mathrm{O}_{2}$ levels were not correlated with lung function and remained elevated despite the improvement in symptoms.

Therefore, $\mathrm{H}_{2} \mathrm{O}_{2}$ seems not to be a useful marker to investigate acute asthma exacerbation.

\section{References}

1 Rosias PPR, Dompeling E, Hendriks HJE, Heijnens JWCM, Donckerwolcke RAMG, Jobsis Q: Exhaled breath condensate in children: pearls and pitfalls. Pediatr Allergy Immunol 2004;15:4-19.

- 2 Horváth I, Hunt J, Barnes PJ: ATS/ERS Task Force on Exhaled Breath Condensate. Exhaled breath condensate: methodological recommendations and unresolved questions. Eur Respir J 2005;26:523-548.

- 3 Dressel H, Müller F, Fischer R, Römmelt H, Hohlfeld JM, Behr J, Huber RM, Nowak D, Jörres RA: Independent information of nonspecific biomarkers in exhaled breath condensate. Respiration 2010;80:401-409.

$\checkmark 4$ Jackson AS, Sandrini A, Campbell C, Chow $S$, Thomas PS, Yates DH: Comparison of biomarkers in exhaled breath condensate and bronchoalveolar lavage. Am J Respir Crit Care Med 2007;175:222-227.

$\checkmark 5$ Corradi M, Zinelli C, Caffarelli C: Exhaled breath biomarkers in asthmatic children. Inflamm Allergy Drug Target 2007;6:150-159.

6 Kostikas K, Koutsokera A, Papiris S, Gourgoulianis KI, Loukides S: Exhaled breath condensate in patients with asthma: implications for application in clinical practice. Clin Exp Allergy 2008;38:557-565.

7 Zietkowski Z, Skiepko R, Tomasiak-Lozowska MM, Mroczko B, Szmitkowski M, Bodzenta-Lukaszyk A: RANTES in exhaled breath condensate of allergic asthma patients with exercise-induced bronchoconstriction. Respiration 2010;80:463-471.
Zietkowski Z, Skiepko R, Tomasiak-Lozowska MM, Bodzenta-Lukaszyk A: Anti-IgE therapy with omalizumab decreases endothelin-1 in exhaled breath condensate of patients with severe persistent allergic asthma. Respiration 2010;80:534-542.

-9 Liu L, Urban P, Hunt JF, Wilkinson P, Laning $\mathrm{K}$, Gaston B: Changes in exhaled nitric oxide and breath $\mathrm{pH}$ during fluticasone wean in asthma. Respiration 2010;79:193-199.

10 Loukides S, Bouros D, Papatheodorou G, Panagou P, Siafakas NM: The relationship among hydrogen peroxide in expired breath condensate, airway inflammation and asthma severity. Chest 2002;121:338-346.

11 Rahman I, MacNee W: Reactive oxygen species; in Barnes P, Drazen J, Rennard S, Thomson N (eds): Asthma and COPD. London, Academic Press, 2002, pp 243-253.

-12 Stolarek R, Bialasiewicz P, Krol M, Nowak D: Breath analysis of hydrogen peroxide as a diagnostic tool. Clin Chim Acta 2010;411: 1849-1861.

13 Teng Y, Sun P, Zhang J, Yu R, Bai J, Yao X, Huang M, Adcock IM, Barnes PJ: Hydrogen peroxide in exhaled breath condensate in asthma: a promising biomarker? Chest 2011; 140:108-116.

14 Jobsis Q, Raatgeep C, Hermans PWM, de Jongste JC: Hydrogen peroxide in exhaled air is increased in stable asthmatic children. Eur Respir J 1997;10:519-521.

15 Dohlman AW, Black HR, Royall JA: Expired breath hydrogen peroxide is a marker of acute airway inflammation in pediatric patients with asthma. Am Rev Respir Dis 1993; 148:955-960.
16 Horváth I, Donnelly LE, Kiss A, Kharitonov SA, Lim S, Chung KF, Barnes PJ: Combined use of exhaled hydrogen peroxide and nitric oxide in monitoring asthma. Am J Respir Crit Care Med 1998;158:1042-1046.

17 Global Initiative for Asthma (GINA): Global strategy for asthma management and prevention. 2008. http://ginasthma.org.

18 Vandenplas Y, Rudolph CD, Di Lorenzo C, Hassall E, Liptak G, Mazur L, Sondheimer J, Staiano A, Thomson M, Veereman-Wauters G, Wenzl TG: North American Society for Pediatric Gastroenterology Hepatology and Nutrition, European Society for Pediatric Gastroenterology Hepatology and Nutrition: Pediatric gastroesophageal reflux clinical practice guidelines: joint recommendations of the North American Society for Pediatric Gastroenterology, Hepatology, and Nutrition (NASPGHAN) and the European Society for Pediatric Gastroenterology, Hepatology, and Nutrition (ESPGHAN). J Pediatr Gastroenterol Nutr 2009;49:498-547.

19 MacGregor G, Ellis S, Andrews J, Imrie M, Innes A, Greening AP, Cunningham S: Breath condensate ammonium is lower in children with chronic asthma. Eur Respir J 2005;26:271-276.

20 Goldoni M, Caglieri A, Andreoli R, Poli D, Manini P, Vettori MV, Corradi M, Mutti A: Influence of condensation temperature on selected exhaled breath parameters. BMC Pulm Med 2005;5:10. 
-21 Caglieri A, Goldoni M, Acampa O, Andreoli R, Vettori MV, Corradi M, Apostoli P, Mutti A: The effect of inhaled chromium on different exhaled breath condensate biomarkers among chrome-plating workers. Environ Health Perspect 2006;114:542-546.

-22 Corradi M, Folesani G, Andreoli R, Manini P, Bodini A, Piacentini G, Carraro S, Zanconato $S$, Baraldi E: Aldehydes and glutathione in exhaled breath condensate of children with asthma exacerbation. Am J Respir Crit Care Med 2003;167:395-399.

23 Corradi M, Alinovi R, Goldoni M, Vettori M, Folesani G, Mozzoni P, Cavazzini S, Bergamaschi E, Rossi L, Mutti A: Biomarkers of oxidative stress after controlled human exposure to ozone. Toxicol Lett 2002;134:219225.

-24 Miller MR, Hankinson J, Brusasco V, Burgos F, Casaburi R, Coates A, Crapo R, Enright P, van der Grinten $C P$, Gustafsson P, Jensen R, Johnson DC, MacIntyre N, McKay R, Navajas D, Pedersen OF, Pellegrino R, Viegi G, Wanger J, ATS/ERS Task Force: Standardisation of spirometry. Eur Respir J 2005;26:319338.

25 Dreborg S: The skin prick test in the diagnosis of atopic allergy. J Am Acad Dermatol 1989;21:820-821.

26 Ganas K, Loukides S, Papatheodorou G, Panagou P, Kalogeropoulos N: Total nitrite/ nitrate in expired breath condensate of patients with asthma. Respir Med 2001;95: 649-654.

27 Robroeks C, van de Kant K, Jobsis Q, et al: Exhaled nitric oxide and biomarkers in exhaled breath condensate indicate the presence, severity and control of childhood asthma. Clin Exp Allergy 2007;37:1303-1131.
28 Loukides S, Kontogianni K, Hillas G, Horvath I: Exhaled breath condensate in asthma: from bench to bedside. Curr Med Chem 2011;18:1432-1443.

29 Gessner C, Kuhn H, Seyfarth H-J, Pankau H, Winkler J, Schauer J, Wirtz H: Factors influencing breath condensate volume. Pneumologie 2001;55:414-419.

30 Vaughan J, Ngamtrakulpanit L, Pajewski T, Turner R, Nguyen TA, Smith A, Urban P, Hom S, Gaston B, Hunt J: Exhaled breath condensate $\mathrm{pH}$ is a robust and reproducible assay of airway chemistry. Eur Respir J 2003; 22:889-894.

31 Schleiss MB, Holz O, Behnke M, Richter K, Magnussen H, Jorres RA: The concentration of hydrogen peroxide in exhaled air depends on expiratory flow rate. Eur Respir J 2000;16: 1115-1118.

32 Franklin P, Moeller A, Hall GL, Horak F Jr, Patterson H, Stick SM: Variability of nitric oxide metabolites in exhaled breath condensate. Respir Med 2006;100:123-129.

33 Horváth I, MacNee W, Kelly FJ, Dekhuijzen PN, Phillips M, Döring G, Choi AM, Yamaya M, Bach FH, Willis D, Donnelly LE, Chung KF, Barnes PJ: Haemoxygenase-1 induction and exhaled markers of oxidative stress in lung diseases. Summary of the ERS Research Seminar in Budapest, Hungary, September 1999. Eur Respir J 2001;18:420.

34 Culpitt SV, Russell REK: The measurement of hydrogen peroxide in airway disease. Eur Respir Rev 1999;68:246-248.

35 Loukides S, Bakakos P, Kostikas K: Exhaled breath condensate: hydrogen peroxide. Eur Respir Monogr 2010;49:162-172.

36 Antczak A, Kurmanowska Z, Kasielski M, Nowak D: Inhaled glucocoticosteroids decrease hydrogen peroxide in expired air condensate in asthmatic patients. Respir Med 2000;94:416-421.
7 Rhen T, Cidlowski JA: Antiinflammatory action of glucocorticoids - new mechanisms for old drugs. N Engl J Med 2005;353:17111723.

8 Rhoden KJ, Barnes PJ: Effect of hydrogen peroxide on guinea-pig tracheal smooth muscle in vitro: role of cyclo-oxygenase and airway epithelium. Br J Pharmacol 1989;98: 325-330.

39 Doniec Z, Nowak D, Tomalak W, Pisiewicz $\mathrm{K}$, Kurzawa R: Passive smoking does not increase hydrogen peroxide $\left(\mathrm{H}_{2} \mathrm{O}_{2}\right)$ levels in exhaled breath condensate in 9-year-old healthy children. Pediatr Pulmonol 2005;39: 41-45.

40 Laughan ML, Spiro DM: Portable spirometry during acute exacerbations of asthma in children. J Asthma 2009;46:122-125.

41 Chan-Yeung M, Chang JH, Manfreda J, Ferguson A, Becker A: Changes in peak flow, symptom score, and the use of medications during acute exacerbations of asthma. Am J Respir Crit Care Med 1996;154:889-893.

- 42 Rosias PP, Robroeks CM, Kester A, den Hartog GJ, Wodzig WK, Rijkers GT, Zimmermann LJ, van Schayck CP, Jobsis Q, Dompeling E: Biomarker reproducibility in exhaled breath condensate collected with different condensers. Eur Respir J 2008;31:934-942.

43 Kazani S, Israel E: EBC in asthma: diagnostic and therapeutic implications. J Breath Res 2010;4:047001.

-44 Corradi M, Goldoni M, Caglieri A, Folesani G, Poli D, Corti M, Mutti A: Collecting exhaled breath condensate (EBC) with two condensers in series: a promising technique for studying the mechanisms of EBC formation, and the volatility of selected biomarkers. J Aerosol Med Pulm Drug Deliv 2008;21: $35-44$.
Caffarelli/Calcinai/Rinaldi/ Povesi Dascola/Terracciano/Corradi 